\title{
THE LUXURIANCE OF A BOG IN ITS NATURAL STATE AS AN INDEX TO THE QUALITY OF ITS PEAT
}

\author{
Viljo PuUstjärvi \\ Department of Agricultural Chemistry, University of Helsinki
}

Received Novemter 16, 1959

When bogs in their natural state are taken into agricultural or silvicultural use, one seeks in the first place to exploit the best bogs, that is, such bogs that will be able in their future mode of use to yield the best possible returns. Therefore, one ought to be able to tell the relative value of a bog in its natural state with a view to its future mode of use. In Finland, the surface vegetation has been taken as a basis for the productivity classification of bogs. The site requirements of bog plants, particularly their relation to the reaction of the substrate (5) and to its nutrient content (4) have been investigated. The more luxuriant the vegetation and the greater particularly the abundance in species of calciphiles, the better is the bog considered to be. The definition of the degree of productivity of a bog has thus become a problem of plant ecology. In dealing with this question, the ecologic bog type system developed by CAJANDER (1) has been employed as an aid. A relative value in use, or so-called degree of quality (specified by classes 1 to 10), characterizing the productivity of the drained bog has been assigned to the different bog types on the basis of their surface vegetation. As its ultimate unit of measurement one uses, in applications of forestry, the annual increment of standing crop, and in agricultural applications the crop yield results obtained by means of conventional cultivation techniques $(7,14)$. This method has found wide application particularly in settlement and forest drainage activities. Its soundness has been investigated, on the basis of field tests, by VALMARI (14) with respect to a gricultural and by Heikurainen (3) with respect to silvicultural applications. Both have found that the system yields fairly good results although it has been necessary to apply some small corrections.

Although the productivity grading system is considered to give correct results as a rule, also cases giving evidence of the contrary have occurred in agricultural (9) as well as silvicultural (10) applications. The deviations from the general rule may be chance occurrences but they may equally indicate the existence of systematic errors. 
When the productivity grading system is employed, the estimated productivity of the drained bog is measured in terms of the luxuriance of the bog in its natural state. Generally, the mutual order with respect to value is assumed to be the same for bogs in their natural state and for the drained bogs. Thus draining is not thought to alter this succession in value in any noteworthy manner. The objective of the present investigation is to give some thought to this question primarily from a theoretical point of view.

The author has previously (10) dealt with the cation uptake of plants as a cation exchange phenomenon in the manner earlier presented by MATTSON and KARLSSON (8), the efficiency of the cation exchange being thought to be determined by the electrical potential difference existing between the root colloids and the soil colloids. The said potential difference (E) can be expressed by by NERNST's formula

$$
\mathrm{E}=\frac{\mathrm{RT}}{\mathrm{nF}} \ln \frac{\left[\mathrm{H}^{+}\right]_{\text {root }}}{\left[\mathrm{H}^{+}\right]_{\text {soil }}}
$$

where $\mathrm{R}$ is the general gas constant, $\mathrm{T}$ the absolute temperature, $\mathrm{n}$ the valence of the ion in question, $\mathrm{F}$ the quantity of electricity carried by one equivalent, and $\left[\mathrm{H}^{+}\right]$stands for the hydrogen ion activities of the root or soil colloids concerned.

In order that the cation uptake of plants might be possible, the activity of the hydrogen ions in the roots must be higher than that in the soil. The quotient $\frac{\left[\mathrm{H}^{+}\right]_{\text {root }}}{\left[\mathrm{H}^{+}\right]_{\text {soil }}}$ will then be greater than unity and the potential difference $\mathrm{E}$ will have a positive value. The potential difference tends to become equalized by exchange of hydrogen ions from the root for base cations in the soil, primarily calcium, potassium and magnesium.

What is going to occur according to NERNST's formula if a bog in its natural state is drained? The activity of the hydrogen ions in the root remains approximately unchanged. In the soil on the other hand, owing to removal of water, the quantity of peat colloids and at the same time also that of hydrogen ions per unit volume increases. The ratio $\frac{\left[\mathrm{H}^{+}\right]_{\text {root }}}{\left[\mathrm{H}^{+}\right]_{\text {soil }}}$ becomes less with progressing draining and it becomes unity when $\left[\mathrm{H}^{+}\right]_{\text {root }}=\left[\mathrm{H}^{+}\right]_{\text {soil }}$. If the original bog was sufficiently wet and if the drainage is highly efficient, $\left[\mathrm{H}^{+}\right]_{\text {soil }}$ may ultimately exceed $\left[\mathrm{H}^{+}\right]_{\text {root }}$ and the potential difference will change its sign. This implies that base cations should start to travel from the roots into the soil; in such a case, naturally, the plants die before long.

When a bog is being drained, also the quantity of exchangeable bases in the peat, per unit volume, increases in addition to the concentration of exchangeable hydrogen ions in the peat. Thus, one might easily think that draining promotes rather than impairs the base supply of the plants. The trend which the development of conditions takes will depend on which factor is decisive with respect to the base nutrition of the plants, the above-mentioned electric potential difference or the quantity of usable bases. 
Let us consider the base contents of the peats in the different productivity classess in order to determine the direction of the said trend. If the quantity of usable, or practically of the exchangeable, bases in the peat were the decisive factor with respect to the base nutrition of the plants, one might in a somewhat schematical way assume that the base status should be approximately the same in bogs in their natural state that have the same trophicity. The base content per dry matter weight of the peat should then become higher as the bog in its natural state becomes more watery.

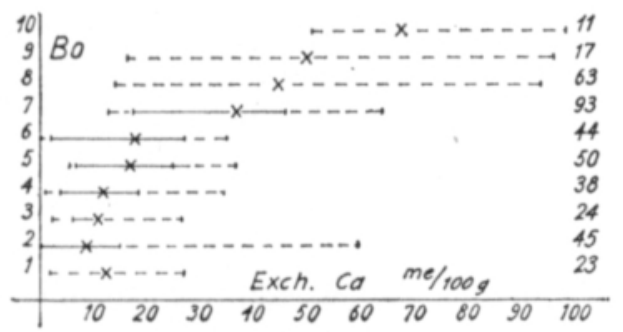

Fig. 1. The relations tetween soil quality class (Bo) and exchangeable calcium.

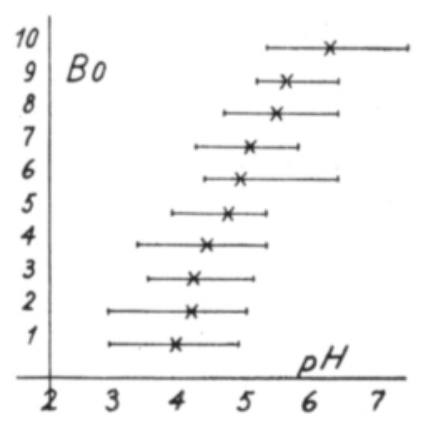

Fig. 2. The relations between soil quality class (Bo) and $\mathrm{pH}$.

In order to study the trend of the phenomenon, surface peat samples were collected from bogs belonging to various productivity classes and the exchangeable calcium was determined, as related to the dry matter weight, for the air-dried samples. Fig. 1 shows the relations between soil quality class and exchangeable calcium. The dotted line and the solid line in combination represent the entire material of investigation. Crosses indicate the average exchangeable calcium quantity (in $\mathrm{me} / \mathrm{l} 00 \mathrm{~g}$ ) of the samples in each soil quality class. The figure reveals that a distinct difference in comparison with lower classes cannot be observed until upwards from soil quality class 7 . Consequently, the exchangeable calcium cannot give any reliable picture of the productivity in individual instances. As can be seen from Fig. 2, the same applies to $\mathrm{pH}$.

For determination of the effect exerted by the degree of moisture content of the bog in its natural state, the bogs were divided into two main groups, i.e., watery and fairly dry bogs. Since the occasional moisture content of the bog is remarkably dependent on the rainfall during the time preceding the sampling, the bog type and the requirements of certain bog plants, particularly of bog mosses in regard to the moisture content of their substrate were employed as a basis of classification. To the group of watery bogs such bog types were referred as treeless Carex bogs, Sphagnum cuspidatum bogs, Sph. papillosum bogs, "rimpi» bogs and fens, and Scorpidium fens. Furthermore, pine bogs with Carex vegetation were referred to the same group insofar the predominant moss species of their wet treeless areas were such Sphagnum mosses of wet sites as those belonging to the Sph. cuspidata group and, moreover, Sph. apiculatum, riparum and papillosum (6). If Sph.parvifolium was the predominant moss, the type was considered to belong to the group of fairly dry bogs. 
The dotted line in Fig. 1 inscribes the area of scattering which contains nothing but fairly dry bogs. The area limited by the solid line includes watery as well as fairly dry bogs.

It can be seen from the figure that watery bogs occurred only in soil quality classes 2 to 7 . Only more or less $S p h$. fuscum-dominated bogs have been referred to soil class 1, and all of them were fairly dry. Among the watery bogs some $S p h$. cuspidatum bogs might have fallen into this class but no such bogs occurred in the present series.

It can be seen from Fig. 1 that the higher soil quality classes (8 to 10) contain no watery bogs at all and, furthermore, that in the lower classes (2 to 7$)$, too, the bogs richest in lime are fairly dry bog types as a rule. Within each soil quality class the bogs were furthermore arranged in a series by decreasing content of exchangeable calcium. It was then found (except for the fact that the bogs richest in lime were fairly dry types) that the most watery bogs were clearly concentrated at the lower end of this series and that moreover the lower end of the series displayed only quite few fairly dry bog types, while practically no fairly dry bog types at all occurred among the bogs poorest in lime even though there are a few exeptions to this. Soil quality class 1 contains only fairly dry bog types but it can indeed be seen that the quantity of exchangeable calcium in this class is on the level of classes 4 to 5 .

Since - as has been noted in the foregoing - the peat of watery bogs contains less calcium, already on the dry matter weight basis, than that of the fairly dry bogs in the same soil quality class, we arrive at an important conclusion from the point of view of the problem under consideration, namely, that there is much less calcium per unit volume in the peat of watery bogs than in that of fairly dry bogs in the same soil quality class in the natural state. The plants will thus obtain the same calcium quantity from a much lower concentration in watery bogs than in fairly dry bogs.

With increasing water content of the peat, the concentration of exchangeable hydrogen ions in the peat and obviously also their activity will decrease. Since the activity of the hydrogen ions on the surfaces of the root colloids of the plants remains unchanged, an increase in water content of the bog will therefore increase the electric potential difference between the root and peat colloids. This provides an explanation of the fact that the plants are able to derive their required base quantities from lower calcium concentrations as the water content of the bog increases. We have thus found that the result supports the theory presented in the foregoing, according to which the base nutrion of the plants is determined by the electric potential difference existing according to NERNST's formula between the root and soil colloids.

On the basis of the preceding theoretical consideration of the phenomenon, we may draw the following practically applicable inferences:

1. The higher the water content of the bog in its natural state and the greater the efficiency of the draining, the farther will the bog's trophicity and soil quality class be separated through the effect of draining. 
2. The lower the water content of the bog in its natural state, the less will its soil quality class decrease through the effect of draining, as compared to its trophicity.

3. When productivity class is measured in terms of trophicity, it is only permissible to compare bogs possessing the same degree of moisture content.

4. When trophicity is employed to measure bogs of different water content, the soil quality class should be lowered in comparison with trophicity, the more the higher the water content of the bog in its natural state.

It is probably impossible, so far, to prove the present theory analytically (with mathematical exactitude). This is primarily due to the circumstance that we cannot determine the hydrogen activities concerned, primarily those of the root colloids, in natural conditions. On the other hand it is possible to investigate to what extent our theory is able to account for the phenomena associated with the draining of bogs. If the theory can furnish an interpretation of phenomena difficult to explain otherwise, this in itself should constitute an indirect argument in favour of the theory. Accordingly, we shall consider some such problems occurring in connection with the draining of bogs.

The difficult afforestation of wrimpin bogs. The soil quality cass of "rimpi» bogs varies between 3 and 7 . However, all such bogs have the feature in common that it is generally rather difficult to make them become forested. This is understandable in the light of the present theory since according to this theory the mrimpin bogs,

Table 1. Degree of moisture content, soil quality class and exchangeable calcium quantity (Ca) in the peat of certain fen types

\begin{tabular}{|c|c|c|c|c|c|}
\hline \multirow{2}{*}{ Fen type } & \multirow{2}{*}{$\begin{array}{l}\text { Rel. height } \\
\text { from ground } \\
\text { water table, } \\
\text { m }\end{array}$} & \multicolumn{2}{|c|}{ Soil quality 7} & \multicolumn{2}{|c|}{ Soil quality } \\
\hline & & $\mathrm{Ca}$ & $\begin{array}{c}\text { Number of } \\
\text { samples }\end{array}$ & $\mathrm{Ca}$ & $\begin{array}{c}\text { Number of } \\
\text { samples }\end{array}$ \\
\hline Scorpidium fen & 3.1 & 37 & 7 & 34 & 6 \\
\hline Intermedius fen & 7.7 & 48 & 5 & 45 & 15 \\
\hline Warnstorfianum fen & 16.1 & 55 & 10 & 57 & 8 \\
\hline
\end{tabular}

being the most watery bog types in existence, should be assigned considerably lowered soil quality classes as compared with their trophicity. Naturally, several other growth factors, such as phosphorus for instance, may equally well frequently constitute the minimum factor.

The soil quality class and base content of the various fen types. The commonest fen types are the Scorpidium, Intermedius and Warnstorfianum fens. The moisture content of these bog types is characterized by the moisture conditions of the growth bases of their dominant moss species (6), which are tabulated in Table 1. This table shows also the distribution of the said bog types by soil quality class and the exchangeable calcium quanities in their peat (in me/100 g). The majority of the Scorpidium fens belonged to soil quality class 6 but since this class did not contain any others of the said fens, it has not been included in the comparisons. 
The table reveals that none of the investigated bog types displays any significant difference with respect to exchangeable calcium between the different soil quality classes. On the other hand there is a distinct difference between the different degrees of moisture content, that is, the higher the water content of the bog type, the lower was the base quantity with which the same degree of luxuriance, or soil quality class, could be obtained. We can thus observe that this result is in support of the theoretical interpretation which was given for the phenomenon.

The decrease of trophicity after draining. When slight draining of watery bogs is carried out (at which the bog vegetation still remains dominant), species that have high growth requirements tend quite generally to disappear in favour of species w.th less exacting requirements. In other words, the trophicity of the bog goes down. This is just what should happen according to the present theory. Of course, the plants have also their specific moisture requirements. However, this alone cannot account for the phenomenon, seeing that the same plants are able to grow even in fairly dry surroundings if their growth site is rich in bases. The moisture requirements of numerous bog plants vary within a fairly wide range (6).

The decrease in production of peatland meadows resultant on draining. There is a frequently observable tendency to present the statement that draining is always and under all circumstances advantageous in regard to the productivity of bogs. According to the foregoing, however, particularly in the instance of watery bogs poor in lime, draining should cause decreased luxuriance and lower productivity of the bog. Now it is known, indeed, that e.g. the productivity of sedge bogs actually decreases as a result of draining. Of course, this has no great significance any more since hay-making on natural meadows has mostly been abandoned nowadays.

In the foregoing, draining has been found to lower the trophicity when watery bogs are concerned. How about the opposite instance? According to our theory watering should increase the trophicity. Increasing water content of the peat is accompanied by decreasing activity of the hydrogen ions so that the potential difference according to NERNST's formula increases, which should result in enhanced cation uptake of the plants and thus also in increased trophicity. Naturally this implies that no factors other than the cations (e.g. phosphorus) act as minimum factors. Let us still consider some practical applications of this reasoning.

Irrigated meadows. Before crop farming became generalized in its present extent, the use of meadows for hay-making was rather common, particularly in Kuusamo in the north-eastern part of our arable region (2). In Kuusamo, for instance, one used to improve the yield of natural meadows by irrigation. We have here an instance in which the trophicity of the bog was increased by increasing its water content.

It is true that the principle involved in the use of irrigated meadows has been explained as being based on the nutrients carried by the surface water (2). No doubt this factor may have even very significant importance but this can hardly apply in all cases. One should keep in mind that the water directed to the meadows consisted mainly of surface water impounded at times of inundation. It is difficult to see how such surface water might have been able to extract nutrients from the soil, which was already fairly strongly leached in most instances. In certain particular 
cases violent, sudden floods may carry quite considerable quantities of silt to the inundated meadows.

The favourable effect of irrigation is further frequently explained as resulting from its action in destroying the mosses of dry substrates. Against this contention one can object that had the nutrient condition been satisfactory during the fairly dry stage, then certainly plants consistent with high trophicity would have thrived on the meadow and no irrigation would have been needed. But since the trophicity was low, it has been necessary to increase it by irrigation, as a consequence of which the mosses having low requirements have made place for the more exacting species.

The peat deposits. Processes corresponding to the principle of irrigating natural meadows occur also of themselves in nature. For one reason or another the bogs may go through dry and watery stages in their history of development. The trophicity of one and the same bog should therefore vary in a manner consistent with such dry and watery periods. For instance, SALmi's (13) investigations concerning the peat deposits of bogs reveal that, e.g., in the Tuulisuo bog at Pelso a Cacex-Sphagnum peat layer overlays the Sphagnum peat and is in its turn covered by sedge peat. The peat layers indicate continuous change toward higher water content of the bog and simultaneous increase of its trophicity. Several examples of this kind can be found in the said peat investigations carried out by SALMI, among them also such instances in which the water content and trophicity of the bog have increased and again decreased in the same profile (12). Except by the peat types, the variations in trophicity are borne out also by the performed peat analyses.

The formation of a given type of bog in a given region is primarily determined by the base content of the water arriving there and by the moisture content of the growth base. Quite often at the performing of productivity grading in the field for purposes of practical use the question comes into ones mind how well one is able by the present soil quality classification system to determine the appropriate productivity, e.g., in such cases in which the base content of the water can be assumed to remain approximately unchanged when the water content of the growth base changes. This becomes an important practical problem for which a solution has to be found in the "aapan bog region when the fairly dry border areas of such watery bogs are graded for productivity. It is known that almost regularly the watery central part of the bog is higher in trophicity than the fairly dry pine bog constituting its border area. As a result of the arability investigation it is recommended

Table 2. Per cent. distribution of bogs and of lands that have become peaty, in the regions of the agricultural societies of Lapland and of Peräpohjola, by cultivability classes.

\begin{tabular}{|c|c|c|c|c|c|c|c|}
\hline \multirow[t]{2}{*}{ Region } & \multicolumn{3}{|c|}{ Bogs } & \multicolumn{4}{|c|}{$\begin{array}{c}\text { Lands that have } \\
\text { become peaty }\end{array}$} \\
\hline & $\begin{array}{c}\text { Cultivable } \\
\%\end{array}$ & $\begin{array}{c}\text { Passable } \\
\text { \% }\end{array}$ & $\begin{array}{c}\text { Poor } \\
\%\end{array}$ & $\begin{array}{c}\text { Cultivable } \\
\%\end{array}$ & $\begin{array}{c}\text { Passable } \\
\%\end{array}$ & $\begin{array}{c}\text { Cultivable } \\
+ \text { Passable } \\
\%\end{array}$ & $\begin{array}{l}\text { Poor } \\
\%\end{array}$ \\
\hline Agr. Soc. of Lapland & 56.1 & 21.2 & 22.3 & 2.2 & 12.3 & 14.5 & 85.5 \\
\hline Agr. Soc. of Peräpohjola & 48.5 & 20.2 & 31.3 & 8.7 & 18.5 & 27.2 & 72.9 \\
\hline
\end{tabular}


that the central part of the bog should be taken into cultivation and the use of its marginal parts should be avoided. Farmers, on the other hand, mostly like to start with the marginal parts since they lie close to the household centre and are easy to drain.

In order to determine the trend of this phenomenon, samples were taken from several bogs from the edge of the mineral soil towards the centre of the bog. Samples were taken every time when a change of bog type or soil quality class was encountered. The soil quality varied between class 2 and 7 on the transects investigated in this manner. The lowest soil quality classes were assigned to the Sphagnum fuscum hummocks and to the oligotrophic pine bogs in the marginal area, while soil quality class 7 could be assigned to grassy Carex bogs and Carex pine bogs closer to the centre of the bog. The series is not so extensive that a reliable picture of the trend could be given on its basis. However, it seems that in such cases the base content of the peat is not correlated with the soil quality class at all but rather tends to retain a constant height. Exceptions occur in either direction. At all events the result is fairly well compatible with the present theory, according to which in cases of this kind the trophicity should increase in the central part of the bog as its growth base increases in water content, while the fairly dry marginal zone should have lower trophicity despite the fact that the base content actually remains unchanged. It would thus appear that there is not much reason to shun the said marginal zones as areas to be taken into cultivation, owing to their low trophicity. Of course, the influence of the base soil has to be taken into account as a separate factor.

The pine bog margins of the maapan bogs discussed in the foregoing are bogs with a shallow peat layer as a rule. Conversely, one may say that at least in NorthFinland bogs with a shallow peat layer are usually pine bogs, which are fairly dry bog types as compared to open bogs. In the light of the present theory the question readily comes to ones mind to what extent there is a tendency in our country to assign too low soil quality classes to pine bogs and particularly to bogs with a shallow peat layer, as compared with fens and treeless bogs.

Some light may perhaps be thrown upon this question by a statistical investigation of the phenomenon. Table 2 gives the per cent. distribution of bogs and of lands that have become peaty, in the regions of North-Finland, into the groups of cultivable, merely passable and poor lands according to investigations carried out in 1923 - 1958 by the Peat Cultivation Society and by the Colonisation Department of the Ministry of Agriculture.

Such bogs have been counted in the statistics as lands that have become peaty in which the peat layers vary between 10 and $30 \mathrm{~cm}$. Their arability is determined by the trophicity of the bog as well as by the quality of the base soil. Most preferably, cultivable land should also have a base soil suited for cultivation. Land that has become peaty is considered passable if the peat layer is cultivable and the base so:l is not singularly stony, or if both peat layer and base soil are passable. Consequently, in relatively more numerous instances lands will be referred to the class of passable lands that have become peaty, merely on the strength of trophicity, than actual bogs are referred to the class of cultivable lands. In spite of this the combined per cent. contribution of cultıvable and passable lands that have become peaty, to the 
total of lands that have become peaty in the regions to which Table 2 refers (12.3 and $18.5 \%$, respectively) is only a fraction of the contribution of cultivable bogs to the entire bog area (56.1 and $48.5 \%$, respectively). However, nature can hardly have distributed the nutrients in such an unequitable manner between the lands that have become peaty and the actual bogs. One should remember that quite on the contrary the base content of the peat layer usually decreases from the bottom of the bog towards its surface with increasing depth of the peat layer. It appears therefore obvious that the soil quality classification system has favoured the actual bogs, which are higher in water content on an average than the lands that have become peaty in the regions now under consideration. If one would insitute a comparison merely between open bogs and lands that have become peaty, the difference would be even greater.

\section{$S u m m a r y$}

From the viewpoint of the chemical properties of peats and of the cation uptake mechanism of plants the question has been considered to what extent it is possible to estimate the productivity after draining of a bog, using as a basis the luxuriance of the bog in its natural state and the richness in species of its calciphilous vegetation. The effect of draining upon the productivity of the peat has been studied from the viewpoint of the cation uptake mechanism of plants. The efficiency of this uptake has been thought to be determined by the electrical potential difference $(\mathrm{E})$ between the boundary surfaces of the root and soil colloids:

$$
\mathrm{E}=\frac{\mathrm{RT}}{\mathrm{nF}} \ln \frac{\left[\mathrm{H}^{+}\right]_{\text {root }}}{\left[\mathrm{H}^{+}\right]_{\text {soil }}}
$$

where $\left[\mathrm{H}^{+}\right]$stands for the activity of the respective hydrogen ions. In order that cation uptake of the plants should be possible, the hydrogen ion acitivity in the roots must exceed that in the soil, i.e., $\frac{\left[\mathrm{H}^{+}\right]_{\text {root }}}{\left[\mathrm{H}^{+}\right]_{\text {soil }}}>1$. When a bog is drained, $\left[\mathrm{H}^{+}\right]_{\text {root }}$ remains approximately unchanged, while $\left[\mathrm{H}^{+}\right]_{\text {soil }}$ soil increases for the reason that the quantity of soil colloids per unit volume increases owing to the removal of water. The potential difference between root and soil colloids will thus become less and the cation uptage of the plants will become impeded, the more the higher the efficiency of draining. The theory presented in this work has been shown to account for several phenomena observed in connection with the draining of bogs, particularly the changes in surface vegetation and the relations between the base content of the bog and its natural luxuriance. The higher the water content of a bog in its natural state, the lower is the base content of the peat with which it attains a given degree of Juxuriance. 
(1) Cajander, A.K. 1913. Studien über die Moore Finnlands. Acta forest. fenn. 2,3: 1-208.

(2) Grotenfelt, G. 1908. Niittyjen vesittäminen Suomessa 1700-luvulla. S. suovilj.yhd. vuosik.: $164-176$.

(3) Heikurainen, L. 1959. Tutkimus metsäojitusalueiden tilasta ja puustosta. Summary: Uber waldbaulich entwässerte Flächen und ihre Waldbestände in Finnland. Acta forest. fenn. 69: $1-279$.

(4) Krvinen, E. Suokasvien ja niiden kasvualustan kasvinravintoainesuhteista. Acta agr. fenn. 27: $1-140$.

(5) Kotilainen, M. J. 1927. Untersuchungen über die Beziehungen zwischen der Pflanzendecke der Moore und der Beschaffenheit, besonders der Reaktion des Torfbodens. S. suovilj. yhd. tiet. julk. $7: 1-219$.

(6) Lumiala, O. V. 1944. Ủber die Beziehung einiger Moorpflanzen zu der Grundwasserhöhe. Geol. seur. julk 16: 147-164.

(7) Lukkala, O. J. \& Kotilainen, M. J. 1951. Soiden ojituskelpoisuus. Helsinki.

(8) Mattson, S. \& Karlsson, N. 1944. The pedography of hydrologic soil series: VI. The composition and base status of the vegetation in relation to the soil. Ann. agr. coll. Sweden, 12: 186202.

(9) PuUstjärvi, V. 1956. On the factors resulting in uneven growth on reclaimed treeless fen soil. Acta agr. scand. 6: 1, 45-63.

(10) - - 1958. Moliniasoiden metsäojitustulosten heikkouteen johtavista syistä. Suo 2: $17-24$.

(11) - 1959. On the cation uptake mechanism of Sphagnum mosses. Maatal.tiet. aikak. 31: $103-119$.

12) SAlmi, M. 1949. Physical and chemical peat investigations on the Pinomäensuo bog, SW. Finland. Bull. com. geolog. Finlande 1945, 1-31.

(13) - - 1952. Turvetutkimuksia Pelson suoalueella. Geotekn. julk. 52: 1-74.

(14) VAlmari, A. 1956. Uber die edaphische Bonität von Mooren Nordfinnlands. Acta agr. fenn. 88, 1: $1-126$.

\section{S E L O S T U S}

\section{LUONNONTILAISEN SUON REHEVYYS TURPEEN LAADUN ILMENTÄJ AN}

$$
\text { Viljo PuUSTJärvi }
$$

Yliopiston maanviljelyskemian laitos, Helsinki

Tutkimuksessa on käsitelty suon trofian ja boniteetin välisiä riippuvaisuussuhteita kasvien kationien oton mekanismin kannalta katsottuna. Teoreettisesti asiaa tarkasteltaessa on päädytty sellaiseen johtopäătōkseen, että suon kuivatus pienentää turpeen kationien käyttőkelpoisuutta. Ilmiön suuntaa ovat vahvistaneet turveanalyysit. Niiden mukaan on samaan boniteettiluokkaan kuuluvien turpeiden emäspitoisuus ollut sitä suurempi, mitä kuivempi suotyyppi on ollut. Samaan boniteettitasoon paaasemiseksi olisi siis nykyistä boniteettisysteemiä käyttäen märkien suotyyppien boniteettia alennettava tai kuivahkojen tyyppien boniteettia kohotettava sitä enemmän mitä kuivempi suotyyppi on. 